\title{
The Causes of Business Cycles and the CyClicality of Real Wages
}

\author{
Charles A. Fleischman* \\ Board of Governors of the Federal Reserve System \\ Mail Stop 80 \\ Washington, DC 20551 \\ email: cfleischman@frb.gov
}

October 1999

\begin{abstract}
A model's ability to explain procyclical movements in real wages has become an important benchmark by which macroeconomists judge business cycle theories. Because Keynesian models with sticky nominal wages predict countercyclical real wages, they have been criticized and dismissed in favor of Real Business Cycle models or New Keynesian models based on price stickiness or countercyclical markups. The bulk of the evidence for procyclical real wages, however, comes from studies using panel data that estimate the unconditional, contemporaneous correlation between real wages and the unemployment rate. These studies constrain real wage cyclicality to be the same irrespective of the source of the business cycle fluctuations. This paper relaxes this constraint and estimates a structural VAR identified by long-run restrictions on the responses of hours and output to labor supply, technology, oil price, and aggregate demand shocks. It finds that real wages are procyclical in response to technology shocks and oil price shocks, but are countercyclical in response to labor supply shocks and aggregate demand shocks. The procyclicality of real wages during the periods covered by the panel data sets may be explained by the importance of the productivity slowdown and the 1970s oil price shocks. The results highlight the limitations of using the unconditional, contemporaneous correlation between real wages and business cycle indicators to sort out competing theories of the business cycle, and cast strong doubt on the appropriateness of the rejection of sticky wage models.
\end{abstract}

Journal of Economic Literature Classifications: E24, E32, E12, C32

Key words: Real Wages, Cyclicality, Business Cycles, Structural VAR

\footnotetext{
*Special thanks to Matthew Shapiro, Robert Barsky, Susanto Basu, Charlie Brown, Carol Evans, Bruce Fallick, Jonathan Parker, John Roberts, and the participants at the High Frequency Economic Fluctuations meeting at NBER Summer Institute 1993 and the Workshop Series at the Division of International Finance of the Board of Governors of the Federal Reserve System for extremely helpful suggestions and conversations, and to the Benard L. Maas Research Foundation for financial support when I was a graduate student at the University of Michigan. Any errors are, of course, my responsibility. The views expressed in this paper are those of the author and do not necessarily reflect those of the Federal Reserve Board or its staff. Tel: (202) 452-6473; fax: (202) 872-4927.
} 


\section{INTRODUCTION}

A model's ability to explain procyclical movements in real wages has become an important benchmark by which macroeconomists judge business cycle theories. McCallum (1986) criticized and dismissed Keynesian models with sticky nominal wages (e.g., Fischer 1977) because these models predict countercyclical real wages. ${ }^{1}$ The main evidence for procyclical real wages comes from panel-data based estimates of the unconditional, contemporaneous correlation between real wages and a cyclical variable (see Bils (1985) and Solon, Barsky, and Parker (1994)). ${ }^{2}$ These studies overturned earlier findings of countercyclical real wages (e.g., Neftci 1978; Sargent 1978) and acyclical real wages (e.g., Geary and Kennan 1982). However, an important limitation shared by the empirical studies based on both the aggregate and panel data is that they constrain real wages to exhibit the same cyclicality, independent of the causes of the fluctuations in output. In fact, many types of economic disturbances can cause business cycles or contribute to the fluctuations in economic activity, including monetary disturbances, credit shocks, consumer confidence (or "animal spirits") shocks, technology or productivity shocks, taste shocks, labor supply shocks, oil price shocks, and exchange rate shocks. Empirical analyses based on structural vector autoregressions (VAR) identify several shocks that cause business cycles and decompose

\footnotetext{
${ }^{1}$ McCallum (1986) summarizes the criticisms of models with sticky nominal wages: "If wage stickiness alone were responsible for the real effects of monetary actions, with product prices adjusting flexibly, then we should observe countercyclical movements in the real wage. That we do not has recently been reconfirmed by Bils (1985)." Models that feature cyclical movements in labor supply (e.g., Barro 1990; Christiano and Eichenbaum 1992) will also generate countercyclical movements in real wages, and thus are subject to the same types of criticisms leveled by McCallum against the Fischer contracting model. Conversely, single shock Real Business Cycle models (e.g., Long and Plosser 1983; Kydland and Prescott 1982, 1990) have been criticized by Christiano and Eichenbaum (1992) for predicting real wage movements more procyclical than those observed, and by King, Plosser, Stock, and Watson (1991) for not allowing a channel through which nominal variables can affect real output. Several New Keynesian models, which attribute movements in real output to the effects of aggregate demand shocks, allow movements in aggregate demand to shift the labor demand curve, and thus predict procyclical real wages. Included under the broad New Keynesian heading are models of imperfect competition with nominal prices stickier than nominal wages (e.g., Mankiw, 1985) and models of imperfect competition with countercyclical markups of price over marginal cost (e.g. Rotemberg and Saloner 1986; Rotemberg and Woodford 1991)--which, in the case of this last group, were developed explicitly to match the prediction of procyclical real wages.

${ }^{2}$ Using data from the National Longitudinal Survey (NLS), Bils (1985) found significantly procyclical real wages over the 1966-1980 period, overturning many years of macroeconomic wisdom. Solon, Barsky, and Parker (1994, SBP) confirmed Bils' findings of real wage procyclicality over a longer period (1967-1987) using data from the Panel Study of Income Dynamics (PSID). SBP argue that aggregate wage measures are subject to a countercyclical composition bias because low-wage (low-skilled) workers tend to account for a larger share of aggregate employment around business cycle peaks than they do at business cycle troughs,
} 
fluctuations in output and other macroeconomic variables into those resulting from each of these shocks (see Blanchard and Watson, 1986; Shapiro and Watson, 1988; Blanchard, 1989; Blanchard and Quah, 1989; King, Plosser, Stock, and Watson, 1991; Gali, 1992). And, Blanchard and Watson (1986) show that the cyclical covariance of real wages varies across postwar business cycles, suggesting that estimates of real wage cyclicality will be sensitive to the combination of shocks that drove any given business cycle. Indeed, Abraham and Haltiwanger (1995) emphasize that Bils and Solon, Barsky, and Parker studied periods with several important supply shocks, including two OPEC oil price shocks and the onset of the "productivity slowdown." This might explain the overall procyclical pattern of real wages found in these two studies, even if long-term nominal wage contracts are important in the transmission of nominal shocks into real fluctuations.

In this paper, I ask two important and related questions. First, do real wages have the same cyclical covariances with output in response to each of the various shocks that drive business cycles? And second, is the evidence of procyclical real wages obtained from panel data studies sufficient to discriminate between competing business cycle models? In answering these questions, I construct measures of conditional wage cyclicality--which I define as the correlation between the forecast errors of output and real wages--separately for each of the shocks. I look beyond estimates of the unconditional, contemporaneous correlation between real wages and cyclical indicators by examining the dynamic responses of real wages and output to the shocks that drive business cycles.

I use a variant of the augmented balanced-growth model presented in Shapiro and Watson (SW, 1988) to identify three aggregate supply shocks--labor supply shocks, technology shocks, and oil price shocks--and two aggregate demand shocks. Identification is based on restrictions on the long-run responses of output, hours and wages to the various shocks. Specifically, labor supply shocks are allowed to have permanent effects on output and hours, but not on real hourly compensation. Technology shocks can have permanent effects on output and hourly compensation, but not on hours worked. Similarly, oil price shocks can have permanent effects on output and wages, as well as on real oil prices, but not on hours worked. Both aggregate demand shocks--a nominal inflation shock and a real rate shock--can have only transitory effects 
on output, hours, and wages. In addition, I add a sixth structural shock, which I call a labor share (or wage) shock. The labor share shock accounts for strictly transitory movements in real hourly compensation not explained by the other five shocks. Examples may include a shock to employers' health insurance costs that is offset in the long-run by a change in wage rates, a transitory change in the real minimum wage, workers' slow incorporation of the implications of the productivity slowdown into their real wage demands, and other shocks to the composition of labor compensation. I restrict this wage shock to have only transitory effects on output, hours, productivity, real wages, and inflation; this last restriction differentiates it from the aggregate demand shocks, which can have permanent effects on inflation.

I find that real wage cyclicality depends on the type of shocks driving the business cycles. Real wages are very procyclical in response to technology shocks and oil price shocks, and mildly countercyclical (or acyclical) in response to labor supply shocks and aggregate demand shocks. These estimates of conditional real wage cyclicality generally match the predictions from Keynesian models of aggregate supply with nominal wages stickier than nominal prices.

Over the period from 1955 to 1998, aggregate supply shocks accounted for more than 76 percent of the unanticipated movements in output after one to four quarters and nearly all of the unanticipated output movements after 16 or more quarters. The eight-quarter and 16-quarter ahead forecast errors in real wages and output are positively correlated, which is consistent with the finding of slightly procyclical aggregate real wages. But, because the competing shocks did not figure equally in each of the post-war business cycles, estimates of unconditional, correlations between real wages and the cycle are not sufficient for discriminating between different business cycle theories. Aggregate demand shocks appear to have played a major role in the recession of 1981-2, and to have contributed to a lesser degree toward the recessions in 1957-58 1960, 196970, 1974-5 and 1980. In contrast, the oil-price shocks in the 1970s appear largely responsible for the recessions in 1974-5 and 1980. Around the same time, the still-largely-unexplained productivity slowdown contributed to slower wage and output growth beginning in the late 1960s or early 1970s. Labor supply shocks were important in nearly all of the post-war economic downturns. Over the 1968 to 1988 period studied by SBP, oil price and technology shocks had a large influence on the pace of aggregate activity and, consequently, real wages appear to be 
somewhat more procyclical than over the full sample period. The heterogeneity of the post-war business cycles makes it impossible to draw conclusions about the relative importance of nominal wage and price stickiness from studies of the unconditional correlation between real wages and output.

These findings of the dependence of real wage cyclicality on the nature of the shocks driving each business cycle are consistent with most other studies that have examined the cyclicality of real wages in response to different shocks affecting the economy. Sumner and Silver (1989) stress that estimates of real wage cyclicality are dependent on the sample period chosen. They find that in years in which there is a positive correlation between change in the inflation rate and change in the unemployment rate (countercyclical inflation), which they interpret as years dominated by aggregate supply shocks, the real wage is procyclical. In contrast, they find that in years in which the change in the inflation rate and the unemployment rate are negatively correlated, the real wage is countercyclical. Liederman (1982) shows that Barro-style unanticipated movements in money supply result in countercyclical real wages. Cogley (1993), using a VAR methodology to test the neutrality of money in the short and medium run, finds that nominal wages are stickier than nominal prices, so that real wages move countercyclically in response to monetary shocks. Blanchard (1989) estimates a VAR identified by contemporaneous restrictions implied by economic theory and finds slightly countercyclical real wages in response to aggregate demand shocks.

Using a VAR identified using long-run restrictions similar to those in this paper, Gamber and Joutz (1997) find a negative correlation between hours and wages in response to aggregate demand and labor supply shocks, and a positive correlation in response to labor demand (technology) and oil price shocks. ${ }^{3}$ However, my specification of the VAR improves upon Gamber and Joutz's in several ways important ways. First, in following Shapiro and Watson, I exploit the dynamics of hours, output, and oil prices to separately identify the three aggregate

\footnotetext{
${ }^{3}$ In earlier work, Gamber and Joutz (1993) found a procyclical response of real wages to aggregate demand shocks. The key difference between these authors' two sets of results likely owes to the different choices of wage measures in the two papers. In Gamber and Joutz (1993), they use average hourly earnings in manufacturing as the wage measure, but in the later work they used hourly compensation (including both wages and benefits) in the nonfarm business sector. I have found that manufacturing wages are significantly more procyclical than hourly compensation in the nonfarm business sector, and that this difference is likely due to the greater cyclicality of hourly wages relative to hourly benefits.
} 
supply shocks. In contrast, Gamber and Joutz use real wages in place of output in their VAR, and, in effect, identify the sources of business cycle fluctuations without reference to fluctuations in output. Second, I treat oil prices as exogenous only through 1985 to correspond to the period when OPEC was able to control prices; Gamber and Joutz (1997) treat oil prices as exogenous over the entire sample period. I find that the time series process for real oil prices appears to have broken sometime during the 1980s, and when I constrain oil prices to have the same effects on the endogenous variables over the full sample period, the two OPEC shocks in the 1970s are misidentified as technology shocks (OPEC I) and aggregate demand shocks (OPEC II). The misclassification of the oil shocks tends to make real wages movements in response to aggregate demand shocks look more procyclical. Third, as in SW, I identify the aggregate demand shocks as the unexplained components in equations for the change in inflation and for the level of the real three-month treasury rate, while Gamber and Joutz (1997) identify aggregate demand shocks from an equation for the unemployment rate. The appeal of the SW specification is that aggregate demand shocks are associated with inflation and interest rate surprises; as expected, positive inflation surprises lead to increases in output and positive interest rate surprises lead to decreases in output. There is no equally appealing rationale for using the unemployment rate equation to identify the aggregate demand shocks, especially in a VAR that already includes hours. I find that when I replace inflation in my VAR with the unemployment rate, real wages are strongly countercyclical in response to aggregate demand shocks, and that aggregate demand shocks explain more of the fluctuations in output at business cycle frequencies, but these results likely obtain because of the difficulty in separating the labor supply shocks from the aggregate demand shocks. Indeed, in the specification including the unemployment rate, labor supply shocks explain less of the variance in output and generate less countercyclical real wages; even more importantly, aggregate demand shocks seem to play a smaller role in causing recessions-especially the recession of 1981-82--in the alternative specification.

The rest of the paper is organized as follows. Section II develops the notion of conditional wage cyclicality and shows how aggregate estimates of real wage cyclicality could depend on the mix of shocks driving business cycles. Section III explains the estimation strategy, 
including the implementation of the Shapiro-Watson long-run identifying restrictions in the VAR. Section IV describes the data. Section V discusses the results. And, Section VI concludes.

\section{CONDITIONAL REAL WAGE CYCLICALITY}

The various structural shocks driving business cycle fluctuations may each generate different correlations between real wages and output. Theoretical models that relax this constraint, including the Fischer (1977) overlapping contracts model, allow both aggregate supply and demand shocks to affect output and can be consistent with different real wage-output correlations in response to the different types of shocks. In the Fischer model, positive aggregate demand shocks (monetary shocks) cause real wages to decline, allowing firms to hire more labor and increase output, and it is this prediction of countercyclical real wages that has been the basis for much of the criticism of sticky wage models. However, the Fischer model also predicts procyclical movements in real wages in response to aggregate supply shocks.

But most empirical studies of real wage cyclicality constrain real wages to have the same covariance with the cycle regardless of the causes of the business cycles. The empirical work can generally be classified into one of three groups: Studies that estimate the coefficient on a contemporaneous cyclical indicator--typically the growth in output, or the level or change in the unemployment rate--in a regression of a measure of real wages on the indicator and other control variables (e.g. Bils, SBP); studies that focus on the dynamic response of real wages estimated from the coefficients in a regression of real wages on its own lags and contemporaneous and lagged values of employment or output (e.g. Neftci 1978; Sargent 1978; Geary and Kennan 1982); and studies that estimate structural VARs and report the impulse response functions for real wages and a cyclical variable--output, employment, or the unemployment rate--to the various shocks identified (e.g. Blanchard 1989; Gamber and Joutz 1993, 1997). Only the studies in this last group relax the constraint that real wages have the identical cyclical correlation in response to all of the disturbances that can cause business cycles.

In this paper, I develop a more useful measure of conditional real wage cyclicality based on the correlations of the responses of real wages and output to aggregate supply and aggregate 
demand shocks. ${ }^{4}$ Following Shapiro and Watson (1988, SW), I estimate a structural VAR and identify aggregate supply and aggregate demand shocks using restrictions on the permanent responses of output, hours, and wages to the different shocks. ${ }^{5}$ The structural VAR can be represented as $C(L) x_{t}=\varepsilon_{t}$, where $\mathrm{C}(\mathrm{L})$ are $n \times n$ matrices of lag polynomials, $\mathrm{x}_{\mathrm{t}}$ is an $n \times 1$ vector of endogenous variables, and $\varepsilon_{\mathrm{t}}$ is an $n \times 1$ vector of structural shocks. The VAR can be inverted and written in its moving average form as $x_{t}=C(L)^{-1} \varepsilon_{t}$. Letting output and real wages be two of the endogenous variables within the VAR, they can be written in their multivariate moving average representations:

$$
\begin{aligned}
& y_{t}=A_{1}(L) \varepsilon_{1 t}+A_{2}(L) \varepsilon_{2 t}+\ldots . .+A_{n}(L) \varepsilon_{n t} \\
& w_{t}=B_{1}(L) \varepsilon_{1 t}+B_{2}(L) \varepsilon_{2 t}+\ldots . .+B_{n}(L) \varepsilon_{n t}
\end{aligned}
$$

where the $\varepsilon_{i t}$ represent the $n$ structural shocks, and the $A_{i}(L)$ and $B_{i}(L)$ are lag polynomials tracing out the response of output and real wages to each of the shocks. I assume that the shocks are serially uncorrelated, mutually independent, and have constant variances:

$$
\begin{array}{lr}
E\left(\varepsilon_{i t} \varepsilon_{i t-s}\right)=0, & s>0 \\
E\left(\varepsilon_{i t} \varepsilon_{j t}\right)=0, & j<>i \\
E\left(\varepsilon_{i t} \varepsilon_{i t}\right)=\sigma_{i}^{2}, & i=1 . . n
\end{array}
$$

I measure real wage cyclicality as the correlation between real output and real wages in response to the structural shocks that drive business cycles. Using the moving-average representations (1) and the properties of the structural shocks (2), the unconditional correlation between output and real wages is:

$$
\operatorname{Corr}\left(y_{t}, w_{t}\right)=\frac{\sum_{i=1}^{n} \sum_{j=0}^{\infty} a_{i j} b_{i j} \sigma_{i}^{2}}{\sqrt{\left(\sum_{i=1}^{n} \sum_{j=0}^{\infty} a_{i j}^{2} \sigma_{i}^{2}\right) *\left(\sum_{i=1}^{n} \sum_{j=0}^{\infty} b_{i j}^{2} \sigma_{i}^{2}\right)}}
$$

\footnotetext{
${ }^{4}$ Gamber and Joutz (1997) report measures of real wage cyclicality based on the single-shock responses of hours and real wages that are similar to the measures described here.

${ }^{5}$ In the next section, I will discuss more completely the Shapiro and Watson's identification of aggregate supply and demand shocks.
} 
If the variances of the shocks, $\varepsilon_{\mathrm{it}}$, are normalized to one, then the unconditional correlation in equation (3) can be written as the weighted sum of the conditional correlations:

$$
\operatorname{Corr}\left(y_{t}, w_{t}\right)=\sum_{i=1}^{n} \frac{\sqrt{\left(\sum_{j=0}^{\infty} a_{i j}^{2}\right)\left(\sum_{j=0}^{\infty} b_{i j}^{2}\right)}}{\sqrt{\left(\sum_{i=1}^{n} \sum_{j=0}^{\infty} a_{i j}^{2}\right) *\left(\sum_{i=1}^{n} \sum_{j=0}^{\infty} b_{i j}^{2}\right)}} \frac{\sum_{j=0}^{\infty} a_{i j} b_{i j}}{\sqrt{\left(\sum_{j=0}^{\infty} a_{i j}^{2}\right)\left(\sum_{j=0}^{\infty} b_{i j}^{2}\right)}}
$$

where the first term after the summation is the weight and the second term is the conditional correlation. Without knowledge of the full history of the shocks, both the weights and the conditional correlations in equation (4) are unobservable. I construct in-sample proxies for the conditional correlations from the k-period ahead forecast errors for real wages and output, defined as:

$$
\begin{gathered}
y_{t+k}^{f e(t)}=y_{t+k}-E_{t-1}\left(y_{t+k}\right)=\sum_{i=1}^{n} \sum_{j=0}^{k} a_{i j} \varepsilon_{i t+k-j} \\
w_{t+k}^{f e(t)}=w_{t+k}-E_{t-1}\left(w_{t+k}\right)=\sum_{i=1}^{n} \sum_{j=0}^{k} b_{i j} \varepsilon_{i t+k-j}
\end{gathered}
$$

Then, for each of the shocks, $\varepsilon_{\mathrm{i}}$, I estimate conditional real wage cyclicality as the correlation between the k-quarter ahead forecast errors for real wages and output, where $\mathrm{k}$ is typically eight quarters:

$$
\operatorname{Corr}\left(y_{t+k}^{f e(t)}, w_{t+k}^{f e(t)} \mid \varepsilon_{i}\right)=\frac{\sum_{j=0}^{k} a_{i j} b_{i j} \varepsilon_{i t+k-j}^{2}}{\sqrt{\left(\sum_{j=0}^{k} a_{i j}^{2} \varepsilon_{i t+k-j}^{2}\right)\left(\sum_{j=0}^{k} b_{i j}^{2} \varepsilon_{i t+k-j}^{2}\right)}}
$$

Estimates of the correlations between the forecast errors (or elasticities of real wages with respect to output) are more useful than comparisons of impulse response functions for describing the cyclicality of real wages in response to the different shocks driving business cycles. ${ }^{6}$ These measures can be compared with estimates of the cyclical correlations from different studies. Moreover, given standard errors for the correlations--which I will construct by monte carlo methods--it is possible to at least informally test whether the differences between the conditional

\footnotetext{
${ }^{6}$ Of course, both the impulse response functions and the conditional correlations are derived from the moving average representations of real wages and output.
} 
correlations in response to the different shocks are statistically significant. Thus, I can explicitly evaluate whether the mild procyclicality of aggregate real wages could, in principle, result from highly procyclical real wages in response to one or more of the structural shocks and countercyclical real wages in response to another of the shocks.

\section{THE MODEL}

\section{Identification of the Structural VAR by Long-Run Restrictions}

I follow Shapiro and Watson $(1988, \mathrm{SW})$ in identifying three types of aggregate supply shocks--labor supply shocks, technology shocks, and oil price shocks--and aggregate demand shocks using long-run restrictions on the responses of output, hours, and real wages. SW's key identifying restriction is that aggregate demand shocks have only transitory effects on output, hours, and wages. SW's identifying restrictions can be viewed a superset of the restrictions used by Blanchard and Quah (1989) to identify a single aggregate supply shock and a single aggregate demand shock by restricting aggregate demand shocks to have only transitory effects on output. SW separately identify the three aggregate supply shocks by imposing additional long-run restrictions: Labor supply shocks can have permanent effects on the level of output and hours worked, but not on the level of real wages; technology shocks can have permanent effects on the level of output and real wages, but not on the level of hours worked; oil-price shocks can have permanent effects on output and real wages, but not on hours worked. Oil-price shocks are differentiated from technology shocks by assuming that oil prices are exogenous.

SW obtain these restrictions from a simple balanced growth model, with the transitory aggregate demand shocks and permanent oil price shocks added. SW modeled the permanent component of output using the Cobb-Douglass value-added production function: ${ }^{7}$

$$
y_{t}^{*}=\alpha h_{t}^{*}+(1-\alpha) k_{t}^{*}+\varepsilon_{t}
$$

${ }^{7}$ All variables are represented in logs. 
where the *'d variables represent the permanent components and $y_{t}$ is real output, $h_{t}$ is hours of all persons, $\mathrm{k}_{\mathrm{t}}$ is the capital stock, $\varepsilon_{\mathrm{t}}$ is the level of technology, and $\alpha$ is the elasticity of output with respect to hours worked.

SW assume that the labor supply curve is completely inelastic and exogenous in the longrun, so that the permanent component of hours, $h_{t}{ }^{*}$, and hence the position of the labor supply curve, is determined solely by the accumulation of past labor supply shocks. This assumption identifies the labor supply shocks. Moreover, along a balanced growth path--where the capitalto-output ratio is constant--this assumption implies that labor supply shocks can have no permanent effects on real wages or measured labor productivity because with a constant capitalto-output ratio and constant-returns-to-scale technology the capital stock evolves according to:

$$
\Delta k_{t}^{*}=\Delta h_{t}^{*}+\left(\frac{1}{\alpha}\right) \Delta \varepsilon_{t}^{*}
$$

In the long run, all markets clear and firms are on their labor demand curves. The long-run marginal product of labor, and hence the long-run real wage, is a function of the capital-to-labor ratio. Technology shocks can have permanent effects on the real wage because in the long run, the capital stock will adjust to technology shocks but the labor force will not. Thus, the long-run level of the real wage will be determined by the position of the long-run labor demand curve:

$$
w_{t}^{*}=(\alpha-1) h_{t}^{*}+(1-\alpha) k_{t}^{*}+\varepsilon_{t}^{*}
$$

where $\mathrm{w}_{\mathrm{t}}{ }_{\mathrm{t}}$ is the long-run level of the real wage. Combining equations (7) and (9), the real wage can be written in terms of hours-worked and output as:

$$
w_{t}^{*}=\left(\frac{1}{\alpha}\right) \varepsilon_{t}^{*} \quad=y_{t}^{*}-h_{t}^{*}
$$

Equation (10) implies that labor's share in costs $\left(\mathrm{w}_{\mathrm{t}}-(\mathrm{y}-\mathrm{h})_{\mathrm{t}}\right)$ must be constant in the long run. However, the dynamics of real wages and average (and marginal) labor productivity are unrestricted in the short and medium term. I add a sixth equation to the Shapiro and Watson model to capture the short-run dynamics in labor share (the difference--in logs--between real hourly compensation and average labor productivity), and I identify a sixth structural shock in part by exploiting the long-run restrictions implied by equation (10): The wage shock (or labor 
share shock) cannot have permanent effects on wages, labor productivity, output or hours. With only these restrictions, the wage shock is indistinguishable from an aggregate demand shock. Thus, identification of the wage shock requires an additional restriction; to this end, I assume that the wage shock--which captures transitory movements in real hourly compensation that cannot be explained by the five other structural shocks--cannot have a permanent effect on inflation. Along these lines, I interpret the wage shocks as shocks to the composition of compensation--such as a shock to benefit costs that is eventually offset by a change in wage rates, a temporary change in the real minimum wage, or workers' slow acceptance of the implications of the change in the growth rate of productivity on the sustainable rate of real wage growth.

To treat oil-price shocks as aggregate supply shocks, SW relaxed the assumption implicit in the balanced growth model that capital-to-output ratio is constant in the long run. ${ }^{8}$ Instead, SW allowed the long-run capital-to-output ratio to be a function of the level of real oil prices. When the price of energy increases, this raises the cost of using capital relative to the cost of using labor, assuming that capital and oil are complements in production. If firms economize on the use of capital, while still treating hours worked as exogenous in the long run, this reduces the capital-to-output ratio, the capital-to-labor ratio, and the levels of real output and wages.

\section{Model Specification and Time Series Properties of the Data}

The estimable model contains five equations--one each for the labor supply shock, the technology shock, the labor share shock, and the two aggregate demand shocks. Equivalently, there is one equation for each of the endogenous variables (hours, productivity, inflation, the real interest rate, and labor's share); I treat oil prices as exogenous. In specifying and estimating the VAR, I consider the time-series properties of the series: The left hand side variables for each equation must be stationary, and all cointegrating relationships must be taken into account. I plot the time series for hours of all persons, output, labor productivity, inflation, real wages, and the

\footnotetext{
${ }^{8}$ In a strict sense, oil-price shocks should not have permanent effects on output when output is measured as value added, as implied by the production function (7) and the choice of data (real gross domestic product in the nonfarm business sector). If a value-added production function exists, then the long-run capital-to-output ratio cannot be affected by real oil prices, and real oil prices can have no permanent effects on output or real wages. By leaving the long-run effects of real oil prices unrestricted, I allow the data to speak to this issue.
} 
real interest rate in the nonfarm business sector in figure 1.

The model assumes that labor force growth and technology growth drive output growth in the long run, and that the levels of both can be represented as integrated processes. The unit-root assumptions for hours worked and labor productivity are appealing. Hours worked can be written as the population times the labor force participation rate times the employment rate times the average workweek. Population growth has varied considerably over the time period, and neither the labor force participation rate nor the aggregate workweek have followed a simple time trend. Similarly, labor productivity does not appear to be trend stationary, at least not around a single trend line over the whole period. The augmented Dickey-Fuller t-statistics for hours, labor productivity, and output are 3.02, 2.16, and 1.14. respectively. ${ }^{9}$ The five and ten percent critical values are -3.45 and -3.15 , indicating that the hypothesis of a unit root cannot be rejected for any of these series, and when estimating the model I specify each of these variables as first differences.

The data provide less guidance for determining the appropriate differencing for the inflation rate. Shapiro (1993) analyzed the times series properties of the inflation rate measured by change in the Consumer Price Index (CPI) and found that the results of unit root tests are sensitive to the choice of sample period. Specifically, Shapiro (1993) found that the longer the period is extended past the disinflation of the early 1980s, the more mean-reverting inflation looks. In addition, inflation is very variable in the Korean War period, and unit-root tests are sensitive to the inclusion of data from the early 1950s. I find a similar sensitivity of the results using the implicit price deflator for the nonfarm business sector (excluding housing). The augmented Dickey-Fuller t-statistic for the presence of a unit root in the inflation rate is -2.32 when the sample period extends from 1954:4 to 1998:4 and 2.57 when the period is extended to cover 1950:4 to 1954:3, compared with the five and ten percent critical values for the augmented Dickey-Fuller tests with no trend of -2.89 and -2.57 , respectively. The hypothesis of a unit root cannot be rejected when the sample excludes the Korean War, and can only be marginally rejected when the Korean War period is included. Moreover, inflation may look more mean reverting

\footnotetext{
${ }^{9}$ All augmented Dickey-Fuller t-statistics reported here are for regressions including six lags and a constant and, unless otherwise noted, are estimated over the 1954:4 to 1998:4 period. The equations used to test for the presence of a unit root in hours, output, labor productivity, real wages, and the difference between labor productivity and real wages all include a time trend. The equations for inflation, the nominal interest rate, and the real interest rate do not include a time trend.
} 
since the early 1980s precisely because monetary policy was successful in eliminating much of the supply-shock-induced inflation that persisted through the 1970s. Shapiro (1993) argues that the disinflation in the early 1980s had a longer-lived effect on inflation than did some of the earlier exogenous changes in monetary policy identified by Romer and Romer (1989). In other words, the disinflation of the early 1980s was a permanent or near permanent shock to the inflation rate. Similarly, the high inflation of the 1970s resulting in part from the two OPEC oil shocks was quite persistent. These experiences suggest that aggregate supply and demand shocks should be allowed to have permanent or very persistent effects on its level. Blough (1991) suggests that in choosing the appropriate differencing for a series, it is important to consider the context in which it is being used. For the purposes here, it is more appropriate to allow the aggregate demand and supply shocks to have permanent effects on the level of inflation and let the data determine their importance, rather than to impose stationarity. Thus, I enter the first difference of the inflation rate in the model.

The real interest rate is defined as the secondary market rate on the three month Treasury Bill minus the contemporaneous rise in the nonfarm business sector price index. The augmented Dickey-Fuller t-statistic for the real interest rate is -2.22 . The hypothesis of a unit root cannot be rejected at the 10 percent significance level (critical value of -2.57). However, economic intuition strongly points to a stationary real interest rate series. For example, the Solow model predicts a constant real interest rate at all steady states, assuming population growth is constant. The stationarity of the change in hours is equivalent to saying that population growth rates are mean reverting. Taking the view that real interest rates are constant in the long run, I treat the real interest rate as stationary.

Equation (10), as well as economic theory, suggests both that real wages follow an integrated process, and that the real wage is cointegrated with labor productivity. In fact, as discussed above, the log difference of real hourly compensation less real labor productivity is the log of labor's share of costs, which appears to be stationary. The augmented Dickey-Fuller tstatistic for the $\mathrm{w}_{\mathrm{t}}-\left(\mathrm{y}_{\mathrm{t}}-\mathrm{h}_{\mathrm{t}}\right)$ is -3.11 , indicating that the hypothesis of a unit root can be rejected at the five percent significance level. 


\section{Estimation Strategy}

Given the results of the unit-root tests and other supporting information, I use the first difference of hours, labor productivity, and inflation, and the level of the real interest rate and labor's share. I write the model in its Wold moving average form as:

$$
\left[\begin{array}{c}
\Delta h_{t} \\
\Delta\left(y_{t}-h_{t}\right) \\
\Delta \pi_{t} \\
r_{t} \\
w_{t}-\left(y_{t}-h_{t}\right)
\end{array}\right]=A(L)\left[\begin{array}{c}
v_{t} \\
e_{t} \\
d_{t}^{1} \\
d_{t}^{2} \\
m_{t}
\end{array}\right]
$$

where $v_{t}$ is the labor supply shock, $\varepsilon_{t}$ is the technology shock, $d_{t}{ }_{t}^{1}$ and $d_{t}{ }^{2}$ are the two aggregate demand shocks, and $\mathrm{m}_{\mathrm{t}}$ is the labor share shock.

Equation (11) can be summarized as $\mathrm{X}_{\mathrm{t}}=\mathrm{A}(\mathrm{L}) \mathrm{s}_{\mathrm{t}}$, where $\mathrm{s}_{\mathrm{t}}$ is the vector of structural shocks. The shocks satisfy the conditions specified in equation (2): they are orthogonal, they each have unit variance, and they are serially uncorrelated. The structural parameters of $A(L)$ cannot be estimated directly. The reduced form is $\mathrm{X}_{\mathrm{t}}=\mathrm{C}(\mathrm{L}) \mathrm{z}_{\mathrm{t}}$, where $\mathrm{E}\left[\mathrm{z}_{\mathrm{t}} \mathrm{z}_{\mathrm{t}}\right]=\Omega, \mathrm{z}_{\mathrm{t}}=\mathrm{A}(0) \mathrm{s}_{\mathrm{t}}$, and $A(L)=C(L) A(0)$. Standard practice is to estimate the autoregressive form, $C(L)^{-1} X_{t}=z_{v}$, and invert to recover $\mathrm{C}(\mathrm{L})$.

Then, to identify $A(L)$ given the estimates of $C(L)$, it is necessary to identify the $n^{2}$ free parameters of $\mathrm{A}(0) .(\mathrm{n}+1) \mathrm{n} / 2$ parameters are identified by the restriction that $\mathrm{A}(0) \mathrm{A}(0)^{\prime}=\Omega$; following Shapiro and Watson (1988), I impose the additional restrictions necessary to identify the structural parameters on the matrix of long-run multipliers, $\mathrm{A}(1)$ : 


$$
A(1)=\left[\begin{array}{ccccc}
a_{11} & 0 & 0 & 0 & 0 \\
0 & a_{22} & 0 & 0 & 0 \\
a_{31} & a_{32} & a_{33} & a_{34} & 0 \\
a_{41} & a_{42} & a_{43} & a_{44} & 0 \\
a_{51} & a_{52} & a_{53} & a_{54} & a_{55}
\end{array}\right]
$$

where the $\mathrm{a}_{\mathrm{ij}}$ represent the long-run effect of the $\mathrm{j}^{\text {th }}$ shock on the $\mathrm{i}^{\text {th }}$ variable. SW obtain the necessary $n(n-1) / 2$ restrictions by imposing that $A(1)$ is lower triangular. I impose the additional restriction that labor supply shocks cannot have any permanent effect on labor productivity or real wages; this restriction is implied by the SW model, but they did not impose it. In addition, I allow both aggregate demand shocks to have permanent effects on inflation by removing the zero restriction on $\mathrm{a}_{34}$. The model, therefore, is exactly identified. I include oil prices as an exogenous variable, and enter the contemporaneous and eight lags of the first difference of real oil prices in each of the equations.

I then follow SW by imposing the restrictions on A(1) through the autoregressive form of the model. For example, the restrictions imply that only labor supply shocks affect hours in the long run. Without these restrictions, the first equation of the VAR is:

$$
\begin{aligned}
\Delta h_{t}= & \sum_{j=1}^{p} \beta_{h h, j} \Delta h_{t-j}+\sum_{j=0}^{p} \beta_{h y, j} \Delta(y-h)_{t-j}+\sum_{j=0}^{p} \beta_{h \pi, j} \Delta \pi_{t-j}+ \\
& \sum_{j=0}^{p} \beta_{h r, j} r_{t-j}+\sum_{j=0}^{p} \beta_{h w, j}(w-(y-h))_{t-j}+\sum_{j=0}^{p} \beta_{h o, j} \Delta o_{t-j}+v_{t}
\end{aligned}
$$

where $\Delta \mathrm{o}_{\mathrm{t}}$ is the change in oil prices. As in SW, I impose the long-run restrictions by constraining the sets of coefficients on the changes in productivity, changes in the rate of inflation, the real interest rate, and the labor share to each sum to zero, which I do by differencing the right hand 
side variables whose associated shocks must have no permanent effects. ${ }^{10}$ In addition, I impose the restrictions that the oil price shocks cannot have any permanent effect on hours by constraining the coefficients on the changes in oil prices to sum to zero. I can rewrite equation (13) as:

$$
\begin{aligned}
\Delta h_{t}= & \sum_{j=1}^{p} \beta_{h h_{j} j} \Delta h_{t-j}+\sum_{j=0}^{p-1} \gamma_{h y, j} \Delta^{2}(y-h)_{t-j}+\sum_{j=0}^{p-1} \gamma_{h \pi, j} \Delta^{2} \pi_{t-j}+ \\
& \sum_{j=0}^{p-1} \gamma_{h r, j} \Delta r_{t-j}+\sum_{j=0}^{p-1} \gamma_{h w, j} \Delta(w-(y-h))_{t-j}+\sum_{j=0}^{p-1} \gamma_{h o, j} \Delta^{2} o_{t-j}+v_{t}
\end{aligned}
$$

Because I place no restrictions on the contemporaneous effects of the shocks on the endogenous variables, the included contemporaneous values of these variables will be correlated with the residual in the hours equation. The model cannot be estimated by OLS. Following SW, I estimate the model with an instrumental variables procedure, using lags 1 through $\mathrm{p}$ of $\Delta \mathrm{h}_{\mathrm{t}}, \Delta(\mathrm{y}-$ $\mathrm{h})_{\mathrm{t}}, \Delta \pi_{\mathrm{t}}, \mathrm{r}_{\mathrm{t}}$, and $(\mathrm{w}-(\mathrm{y}-\mathrm{h}))_{\mathrm{t}}$, and lags 0 through $\mathrm{p}$ of $\Delta \mathrm{o}_{\mathrm{t}}$ as instruments. The equations can be ordered as in equation (11) and estimated in sequence. The residuals from the prior equations are also valid instruments and are used. For example, the residual from the hours equation is used as an instrument in each of the last four equations. ${ }^{11}$

Including the residuals from the prior equations as instruments imposes 10 orthogonality conditions on the covariance matrix of the estimated residuals. The restrictions on the structure of $\mathrm{A}(1)^{-1}$ directly impose 11 restrictions on $\mathrm{A}(0) .{ }^{12}$ An additional five restrictions come from the normalization $\mathrm{E}\left[\mathrm{s}_{\mathrm{t}} \mathrm{S}_{\mathrm{t}}{ }^{\prime}\right]=\mathrm{I}$. Together, there are 26 restrictions used to identify the 25 parameters in $\mathrm{A}(0)$. In practice, the overidentification results in a small correlation between the labor supply

\footnotetext{
${ }^{10}$ The following is an example of how double differencing works: Suppose that $B_{h h, j}=0$ for $j=1$ to $p$ and there is a unit sized shock to oil prices in period $\mathrm{t}$, and no other shocks. Using equation (10), $\Delta \mathrm{h}_{\mathrm{t}}=\gamma_{\mathrm{ho}, 0}, \Delta \mathrm{h}_{\mathrm{t}+1}=-\gamma_{\mathrm{ho}, 0}+\gamma_{\mathrm{ho,1}}, \Delta \mathrm{h}_{\mathrm{t}+2}=-\gamma_{\mathrm{ho}, 1}$ $+\gamma_{\mathrm{ho}, 2}, \Delta \mathrm{h}_{\mathrm{t}+3}=-\gamma_{\mathrm{ho}, 2}+\gamma_{\mathrm{ho}, 3}, \Delta \mathrm{h}_{\mathrm{t}+4}=-\gamma_{\mathrm{ho}, 3}+\gamma_{\mathrm{ho}, 4}, \Delta \mathrm{h}_{\mathrm{t}+5}=-\gamma_{\mathrm{ho}, 4}+\gamma_{\mathrm{ho}, 5}, \Delta \mathrm{h}_{\mathrm{t}+6}=-\gamma_{\mathrm{ho}, 5}$. This sums to zero. If the net change in $\Delta h_{t}$ is equal to zero, then there is no long-run effect of oil price shocks on the level of $h_{t}$. This holds more generally if the roots of $B(L)$ in $[1-B(L)] \Delta h_{t}=G(L) \omega_{t}$ lie outside the unit circle and the coefficients of $G(L)$ sum to zero. The first condition is satisfied if the univariate process for $\Delta h_{t}$ is stationary; the second condition is satisfied by the double differencing of real oil prices in equation (14).

${ }^{11}$ Because oil prices are assumed to be exogenous, no "oil price" equation is estimated.

${ }^{12}$ The two demand shocks are not separately identified, so I avoid analysis of the separate effects of the two demand shocks on output and the real wage.
} 
and technology shocks; because this correlation is small, the imposition of complete orthogonalization on the covariance matrix of the shocks has trivial effects on the results presented below.

\section{Oil Prices}

As discussed above, I allow the changes in real oil prices to be exogenous to the model. However, I find that the time-series process for oil prices appears to have changed sometime in the mid-1980s. I plot the time series for real and nominal oil prices in figure 2 . Through the early 1980s, nominal crude oil prices were set largely by the OPEC cartel, and, before that, the Texas Railroad Commission. Until the first OPEC oil price shock in 1973, the price of crude oil (in current dollars) tended to remain relatively constant for long periods and to be adjusted in discrete increments. But, beginning sometime during the mid-1980s, oil prices became more volatile and began to more closely resemble other commodity prices series.

In order to include oil prices in the model and obtain sensible estimates for the effects of oil prices on the endogenous variables, I must account for this change in time series properties. To do this, I assumed that oil prices were exogenously determined from the beginning of the sample through the end of 1985, and endogenously determined since 1986. Specifically, I set the oil price shock to be equal to the change in oil prices through 1985 and zero since. To determine the break point for the oil price series, I examined the correlogram of the real oil price series allowing for breaks in the process between 1979 and 1988, but found no conclusive break point. ${ }^{13}$ I chose to break the series in 1985:4--the last quarter before oil prices plunged--because of the additional difficulties raised by the possibility that oil price shocks have asymmetric effects on output (see Mork 1989). The results are generally insensitive to the choice of break point between 1982 and 1985, however, when I break the series after 1985 (or include no break at all),

\footnotetext{
${ }^{13}$ Hooker (1999) finds evidence that the relationship between oil prices and the macroeconomy established by Hamilton (1983) broke down in the mid-1980s. He tests whether oil prices Granger cause output growth. He finds that oil prices are significant in all regressions at better than the 10 percent level when the sample period ends prior to 1983 . When the sample period extends past the early 1980s, Hooker finds that oil prices do not Granger cause output or other macroeconomic indicators.
} 
I find that oil prices have only a small effect on output and wages, and that the two OPEC shocks are misidentified as technology and aggregate demand shocks, respectively.

\section{DATA SOURCES}

All data series are quarterly and seasonally adjusted, unless otherwise indicated. All series are widely available. Real output is measured as real gross domestic product (GDP) of the nonfarm business sector (excluding housing) in chained 1992 dollars. I follow Shapiro and Watson in choosing a narrower definition of output than aggregate GDP. The Bureau of Economic Activity (BEA) constructs the GDP data from a variety of sources; output in the government sector, the farm sector, and in housing are difficult to measure, and in computing the official productivity statistics, the Bureau of Labor Statistics (BLS) excludes these sectors. The price measure is the implicit price deflator for the nonfarm business sector (excluding housing). The hours measure is hours of all persons in the non-farm business sector (excluding housing), which BLS uses in producing the statistics on productivity and costs. Nominal oil prices are measured as the producer price index for crude oil and are not seasonally adjusted. The nominal interest rate is the market rate on U.S. three month treasury bills.

I use total nominal hourly compensation for all persons in the nonfarm business sector, which BLS also produces for the productivity and cost release. I chose this compensation series instead of the more common series on wages and salaries of production and non-supervisory workers in manufacturing because it provides broader coverage and is more comparable with the output and hours and output series I use. To construct real hourly compensation, which I refer to liberally in the text and tables as real wages, I deflate by the price series.

\section{V. $\underline{\text { RESULTS }}$}

I estimate the model described above using eight lags of each of the variables over the period from 1955:4 to 1998:4, and present the measures of conditional wage cyclicality derived in 
Section II. ${ }^{14}$ In brief, I find that real wages move procyclically (are positively correlated with output) in response to technology shocks and oil price shocks, and move countercyclically (are negatively correlated with output) in response to labor supply shocks and aggregate demand shocks. I present the key results in tables 1 and 2, and figure 3. Table 1 reports estimates for two measures of conditional wage cyclicality. The top panel shows the correlations between the forecast errors in output and real wages in response to all of the shocks together and each shock individually, and the bottom panel reports the estimates of the elasticity of the forecast errors in real wages with respect to output in response to each of the shocks. Figure 3 presents these results graphically by plotting the eight-quarter ahead forecast errors of output and real wages in response to the labor supply shocks (panel a), oil price shocks (panel b), technology shocks (panel c), and aggregate demand shocks (panel d). Table 2 shows the decomposition of the total forecast error variances in output (top panel) and real wages (bottom panel).

Combining the effects of all the shocks, the eight-quarter ahead forecast errors for output have the same general cyclical properties as the actual series: Output falls in each of the recessions, and the largest declines were observed during the two deepest post-war recessions in 1974-75 and 1981-82. As shown in the top rows in table 1, the total forecast errors in output and real wages are procyclical, and the procyclicality is statistically significant. Based on the eightquarter ahead forecast errors, the correlation between real wages and output in response to all of the shocks is 0.48 (with a standard error of 0.15 ), and the elasticity of real wages with respect to output is 0.26 (with a standard error of 0.09 ). ${ }^{15}$

\footnotetext{
${ }^{14}$ The full sample runs from 1953:4 to 1998:4, but is shortened by the inclusion of eight lags of the exogenous and endogenous variables. I ran likelihood ratio tests to determine the optimal lag length. I tested eight lags vs. six lags and found that I could reject the hypothesis that the last two lags of all variables in all equations were zero. I tested six vs. four lags and found that I could not reject that the last two lags were zero. I tested eight vs. four lags and found that I could reject that the last four lags were zero. Finally, I tested ten vs. eight lags and found that I could reject that the last two lags were zero. I chose to use eight lags rather than ten as a nod towards parsimony. The results are not sensitive to the choice of eight lags vs. ten. The results are sensitive to the choice of eight lags vs. six in the sense that with eight lags I find that real wages are (statistically insignificantly) countercyclical in response to aggregate demand shocks, whereas for six lags I obtained a point estimate of nearly zero for the correlation between output and real wages in response to aggregate demand shocks.

${ }^{15}$ The standard errors were calculated by bootstrapping the residuals 1000 times, regenerating the series using the estimated coefficients from the VAR, and then reestimating the model; throughout the iterations, I assume that real oil prices are exogenous.
} 
Turning now to the forecast errors in response to the individual shocks, the variance decomposition in table 2 shows that aggregate supply shocks account for more than three-fourths of the variance in output and well more than half of the variance in wages at all horizons; of course, the identifying restrictions that aggregate demand and labor share shocks cannot have any permanent effects on output, hours, and wages forces the aggregate supply shocks to explain all of the forecast error variance at long horizons.

\section{Labor Supply Shocks}

As shown in the second row of table 1, real wages move countercyclically in response to labor supply shocks, although the standard error is quite large. ${ }^{16}$ This result is consistent with the shifting of a labor supply curve along a downward sloping labor demand curve. As shown on figure 3, these shocks played some role in the recessions of 1957-58, 1960-61, 1969-70, 1980, and 1981-82, and were an important driving force behind the recession in 1990-91. In addition, the slow recovery of the labor market following the last recession is attributed to labor supply shocks. Overall, the labor supply shocks explain one-third of the forecast error variance in output, but substantially less of the forecast error variance in real wages.

\section{Oil Price Shocks}

The model identifies the two OPEC-led price increases in the 1970s as major contributing factors to the recessions in 1974-5 and the double-dip recessions of 1980 and 1981-82. Ha milton (1983) points out that oil price increases also preceded earlier recessions, and some mild recessionary effects in the 1957 recession are apparent. Overall, oil price shocks explained about 10 percent of the forecast error variances in output and wages after 8 quarters. As shown on figure 3, real wages and output move closely together in response to the oil shocks, indicating

\footnotetext{
${ }^{16}$ In the tables, I report the value of the statistic (e.g. the correlation of the eight-quarter ahead forecast errors in real wages and output in response to labor supply shocks) estimated from the original model and standard errors derived from the bootstrapping. However, in many cases, the mean of the statistic from the bootstrapping exercise differs from the value of the statistic obtained by estimating the model using the actual data. In this specific case, the mean of the correlation based on the bootstrapped residuals is -0.49 , which is about half of the estimated value. Because the bootstrapping is based on the estimated coefficients and residuals from the model, one might interpret the difference between the mean and the actual estimated value as an estimate of the bias in the statistic.
} 
that real wages are procyclical in response to oil price shocks; the correlation between the forecast errors in real wages and output after eight quarters is 0.98 (with a standard error of 0.10 ), and the output elasticity of real wages is 0.50 (with a standard error of 0.19 ).

Following an oil price shock, output and real wages are lower. Although this is inconsistent with the simple value-added production function in equation (7) it might reflect some complementarity between energy and capital usage in production. If energy becomes more expensive, firms may want to economize on its use by substituting labor input for capital and energy inputs. In the short run, capital and labor may not be very substitutable in a given production process, and labor may be relatively immobile across industries. So, even if the longrun effect is that for a given capital stock firms would increase their demand for labor, in the short run firms will find it difficult to make this substitution and unprofitable to utilize all of their capital. Effective labor demand will decrease in the short run. In the long run, firms will use less capital in production but will be able to substitute labor for capital so the capital-to-labor ratio and the marginal product of labor would both be lower. And, since labor supply is completely inelastic and exogenous in the long run, output must be lower if the capital stock is lower. The difference between the short- and medium-run substitutability of capital and labor might explain the sharp drop in output in the short run and the partial recovery just a few quarters later.

Rotemberg and Woodford (1993) show that the procyclicality of real wages and the sharp drops in output associated with the oil price shocks found using value-added data are puzzling unless there is imperfect competition and countercyclical markups of prices over marginal costs. They argue that a constant or procyclical markup is not able to explain the large decline in output and real wages in response to oil price shocks apparent in the impulse response functions. However, the procyclicality of real wages in the short run in response to oil price shocks is consistent with the more traditional notion of oil price shocks as aggregate supply shocks. If an increase in oil prices shifts the aggregate supply curve upward and to the left along a stable aggregate demand curve, output should fall and prices should increase. ${ }^{17}$ If nominal wages are

\footnotetext{
${ }^{17}$ However, oil price shocks are not the same as technology shocks. While a technology shock can shift the production function, oil price shocks cause firms to move along the production function by varying their relative factor utilizations in response to changes in factor prices. Oil price shocks shift the aggregate supply curve because they affect the marginal cost of production, given labor and capital inputs.
} 
stickier than nominal prices, the increase in the price level will result in decreases in the real wage. Alternatively, an oil price shock can be characterized as a shock to the labor demand curve. In a market clearing model, a shift in the labor demand curve along a stable labor supply curve moves hours and wages in the same direction.

\section{Technology Shocks}

As shown in panel c of figure 3, real wages and output move very closely together in response to technology shocks. The estimated correlation between the eight-quarter ahead forecast errors in output and real wages is 0.98 (with a standard error of 0.25 ) and the estimated output elasticity of real wages with respect to output in response to technology shocks is 0.66 (with a standard error of 0.44 ).

Technology shocks are an importance source of the fluctuations in output: Overall, technology shocks explain about 50 percent of the forecast error variance in output on impact, roughly 40 percent of the variance at four, eight, and sixteen quarters, and well more than half of the variance at long horizons. They are even more important in explaining the dynamics of real wages: At four quarters they explain two-thirds of the forecast error variance in real wages and by 16 quarters they explain more than 80 percent of the variance. Technology shocks appear to have contributed to the recessions in 1960-61, 1973-75, and 1981-82, but do not appear to be the key driving force behind any of the post-war recessions analyzed here. On the other hand, the forecast errors in output explained by technology shocks seem to capture the "productivity slowdown" that began sometime in the late 1960s or early 1970s. The forecast error in output due to technology shocks averaged more than 1 percent from 1957 to 1973 , and nearly -1 percent from 1974 to 1998. By way of comparison, the forecast errors due to oil price shocks and labor supply shocks also differed between the two subperiods, but by less than one percentage point; moreover, the forecast errors due to aggregate demand shocks averaged very close to zero in both sub periods.

Clearly, treating the productivity slowdown as endogenous dominates the estimates of the technology shocks. As an alternative, I reestimated the model adding dummy variables for the post-1973 period to each equation. In the labor productivity equation, the dummy variable 
soaked up the difference in the mean growth rates across the pre- and post-1973 period, in effect making the productivity slowdown exogenous. This, in turn, reduced the forecast error variances for labor productivity, output, and real wages, and reduced the role of the technology shocks in explaining the forecast error in output; in this alternative specification, technology shocks explained only 8 to 20 percent of the forecast error variance in output over the first eight quarters, as compared with between 35 and 50 percent in the base case. In addition, because technology shocks are less important as a source of fluctuations in output once the dummy variables are included in the model, the estimates of the correlation of the overall forecast errors in real wages and output and of the output elasticity of real wages are both reduced notably. The estimates of the other correlations are essentially unchanged.

\section{Aggregate Demand Shocks}

I follow Shapiro and Watson (1988) by including two separate aggregate demand shocks that, over time, each contributed different amounts to the fluctuations in output. Negative aggregate demand shocks were an important cause of the recession of 1982, and appear to have at least been a contributing factor to most of the other recessions. But, over the full sample period the dominant causes of output fluctuations were aggregate supply shocks; aggregate demand shocks explain at most 17 percent of the forecast error variance in output (at the fourquarter horizon), and even less of the forecast error variance for real wages. The appeal of the SW specification is that aggregate demand shocks are associated with inflation and interest rate surprises, and, as expected, positive inflation surprises lead to increases in output and positive interest rate surprises lead to decreases in output. However, including two separate aggregate demand shocks results in a somewhat less consistent relationship between the output and real wage movements in response to the aggregate demand shocks.

The cyclicality of real wages in response to aggregate demand shocks is of key interest for discriminating between different business cycle theories. As discussed above, sticky-wage models

of the business cycle are perfectly consistent with procyclical real wages in response to aggregate supply shocks as well as with countercyclical real wages in response to aggregate demand shocks. I find that in response to aggregate demand shocks, the eight-quarter ahead forecast errors in real 
wages and output negatively correlated (correlation $=-0.49$ ), but imprecisely estimated (standard error of 0.52). ${ }^{18}$ Similarly, the estimated output elasticity of real wages is negative $(-0.12)$ but has a large standard error $(0.25)$. Given the wide confidence bands, this provides only limited evidence that real wages are countercyclical in response to aggregate demand shocks.

When I change the specification to bring it closer to that used by Gamber and Joutz (1997) by replacing the inflation equation with an equation for the unemployment rate, real wages are strongly countercyclical in response to aggregate demand shocks, and aggregate demand shocks explain more of the fluctuations in output at business cycle frequencies. There is, however, no particularly appealing rationale for using the unemployment rate equation to identify the aggregate demand shocks, especially in a VAR that already includes hours. In fact, it is likely that the estimates of greater countercyclicality of real wages in response to aggregate demand shocks in this alternative specification obtain because of the difficulty in separating the labor supply shocks from the aggregate demand shocks; indeed, in the alternative specification, labor supply shocks explain less of the variance in output and generate less countercyclical real wages. And, more importantly, in the alternative specification, aggregate demand shocks seem to play a smaller role in causing recessions--especially the recession of 1981-82.

The estimates of the correlation between the forecast errors in output and real wages in response to aggregate demand shocks are somewhat sensitive to other choices of model specification. When I estimate the model using six lags rather than eight, I find that in response to aggregate demand shocks, real wages and output are essentially uncorrelated (correlation $=0.09$ with a standard error of 0.47 ), and just as in the base case, output movements arising from aggregate demand shocks are not associated with any sizeable movements in real wages (the output elasticity of real wages $=0.02$ with a standard error of 0.26 ). However, focusing only on the estimate of the contemporaneous correlation can be misleading. Indeed, the cross correlogram between the forecast errors in output and real wages shows that even though wages and output are roughly uncorrelated contemporaneously, the period t forecast error in wages is negatively correlated with the period $t+i$ forecast errors in output, where $i=1$ through 15 . The

\footnotetext{
${ }^{18}$ According to the bootstrapping exercise I use to generate the standard errors, the mean of the distribution of correlations between real wages and output in response to aggregate demand shocks is very close to zero.
} 
negative correlation peaks at -0.32 after five quarters. Given the lengths of employment contracts and the frequency of wage changes, there should be a negative correlation between the forecast errors in wages and output at relatively high frequencies, but this relationship need not be contemporaneous. ${ }^{19}$ Thus, the time series evidence based on the estimates of the model using six lags can be interpreted as consistent with at least some role for wage stickiness in propagating the effects of aggregate demand shocks on real output.

The estimates of the real wage-output relationship in response to aggregate demand shocks is also sensitive to the treatment of real oil prices in the model. In the featured estimates, I assume that real oil prices are exogenous through the end of 1985, and endogenous thereafter. If instead I assume that real oil prices are fully exogenous and I constrain oil price shocks to have the same effects on the endogenous variables over the entire sample period, I find that real wages are procyclical in response to aggregate demand shocks (correlation $=0.26$ ). However, this result appears to be driven by the misclassification of the second OPEC shock as an aggregate demand shock. ${ }^{20}$ In contrast, when I treat oil prices as exogenous over the full sample period but allow the pre- and post-1985 shocks to have different effects, I find that the OPEC shocks are not misclassified and that real wages move countercyclically in response to aggregate demand shocks; moreover, I find in this more flexible specification, that the post-1985 oil shocks had little effect on output or the other endogenous variables.

\section{Sensitivity of the Estimates of Real Wage Cyclicality to the Choice of Time Period}

Given that real wages have different covariances with output depending on the types of shock driving output fluctuations and that different types of shocks were important during different time periods, it follows that estimates of the cyclicality of real wages should be sensitive to the choice of sample period. In the top panel of figure 4, I report the estimated coefficients on the total eight-quarter ahead forecast error in output from the regression of the forecast error in

\footnotetext{
${ }^{19}$ Den Haan (1996) makes the point that wage stickiness implies a relationship between real wages and employment at high frequencies, but not necessarily at low frequencies.

${ }^{20}$ The first OPEC shock is misidentified as a technology shock. In fact, when oil prices are assumed exogenous over the full sample period, oil price shocks explain little of the forecast error variance in output at all frequencies.
} 
real wages on the forecast error in output from overlapping 20 year sample periods. As shown in the figure, real wages are estimated to be quite procyclical when the sample period includes the 1960s. When the sample period begins in the late 1970s, real wages are estimated to be roughly acyclical. The estimated coefficient peaks when the sample period runs 1966 to 1986--the period including the productivity slowdown as well as the two OPEC shocks, and nearly the same period used by Solon, Barsky, and Parker (1994) when they found that real wages are significantly procyclical. The bottom panel of figure 4 shows the estimates of the coefficients on the change in the unemployment rate from a regression of the growth in real wages on the change in the unemployment rate using published data. Again, this figure shows that the estimates of real wage cyclicality are sensitive to the choice of time period, that they show the greatest procyclicality in the aggregate real wage during the period including the productivity slowdown.

\section{CONCLUSIONS}

In this paper, I ask the important question of whether real wage cyclicality can be accurately characterized by the unconditional, contemporaneous correlation between real wages and output, employment, or the unemployment rate. Studies using panel data have found that real wages are significantly procyclical. These studies, however, constrain real wages to have the same cyclical covariance during all business cycles, although the business cycles can have several causes.

Using a variant of the model in Shapiro and Watson (1988), I study the dynamic responses of real wages to a variety of shocks that cause business cycles. I find that there are important differences in the cyclicality of real wages in response to the structural shocks. I find that labor supply shocks and aggregate demand shocks cause countercyclical movements in real wages. Technology shocks and oil price shocks, which can both be interpreted as labor demand shocks, cause real wages to move procyclically.

The estimated cyclicality of real wages in response to labor supply shocks and technology shocks should be uncontroversial. There is, however, little agreement in the literature on how real wages should behave in response to aggregate demand shocks. Sticky nominal wage models fell out of favor with macroeconomists when recent evidence showed that real wages are procyclical. 
Recent models in which most movements in output are due to movements in aggregate demand are consistent with the evidence showing procyclical real wages. Unlike sticky wage models, sticky price models and models based on countercyclical markups of price over marginal cost generate procyclical real wages in response to aggregate demand shocks.

The findings in this paper demonstrate that simple summary statistics based on the unconditional, contemporaneous correlation between real wages and output, employment, or the unemployment rate are not sufficient to discriminate between competing models of the business cycle. They also suggest that models explaining business cycles as the result of fluctuations in aggregate demand need not be constrained in order that their predictions match the stylized fact of an overall procyclical real wage. Countercyclical or acyclical real wage responses to aggregate demand shocks are consistent with an overall procyclical real wage because of the substantial procyclicality of the real wage in response to oil price and technology shocks. The evidence in this paper casts doubt on the appropriateness of rejecting sticky wage models because of their predictions of countercyclical real wages. 


\section{References}

Abraham, Katharine G. and John C. Haltiwanger. 1995. "Real Wages and the Business Cycle." Journal of Economic Literature. 33:3. P. 1215-1264.

Barsky, Robert B. 1987. "The Fisher Hypothesis and the Forecastability and Persistence of Inflation." Journal of Monetary Economics. 19:1. p. 3-24.

Bils, Mark J. 1985. "Real Wages over the Business Cycle: Evidence from Panel Data." Journal of Political Economy. 99:4. p. 666-689.

Blanchard, Olivier J. 1989. "A Traditional Interpretation of Macroeconomic Fluctuations." The American Economic Review. 79:5. p. 1146-1164.

Blanchard, Olivier J. and Danny Quah. 1989. "The Dynamic Effects of Aggregate Demand and Aggregate Supply Disturbances." The American Economic Review. 79:4. p. 655-673.

Blanchard, Olivier J. and Mark W. Watson. 1986. "Are All Business Cycles Alike?" in Robert J. Gordon, ed. The American Business Cycle: Continuity and Change. Chicago: University of Chicago Press.

Blough, Stephen R. 1991. "The Relationship Between Power and Level for Generic Unit Root Tests in Finite Samples." Unpublished manuscript, The Johns Hopkins University.

Christiano, Lawrence J. and Martin Eichenbaum. 1992. "Current Real-Business-Cycle Theories and Aggregate Labor-Market Fluctuations." The American Economic Review. 82:3. p. 430-450.

Cogley, Timothy. 1993. "Empirical Evidence on Nominal Wage and Price Flexibility." Quarterly Journal of Economics. 108:2. p. 475-491.

Den Haan, Wouter J. 1996. “The Comovements between Real Activity and Prices at Different Business Cycle Frequencies." Unpublished Manuscript, University of California, San Diego.

Fischer, Stanley. 1977. "Long-Term Contracts, Rational Expectations, and the Optimal Money Supply Rule." Journal of Political Economy. 85:4. p. 191-205.

Gali, Jordi. 1992. "How Well Does the IS-LM Model Fit Postwar U.S. Data." Quarterly Journal of Economics. 107:2. p. 709-738. 
Gamber, Edward N. and Frederick L. Joutz. 1993. "The Dynamic Effects of Aggregate Demand and Supply Disturbances: Comment." The American Economic Review. 83:5. p. 13871393.

Gamber, Edward N. and Frederick L. Joutz. 1997. "Real Wages over the Business Cycle." Eastern Economic Journal. 23:3. P. 277-291.

Geary, Patrick T. and John Kennan. 1982. "The Employment-Real Wage Relationship: An International Study." Journal of Political Economy. 90:4. p. 854-871.

Hamilton, James D. 1983. "Oil and the Macroeconomy since World War II." Journal of Political Economy. 91:2. p. 228-248.

Harvey, Andrew C. 1990. The Econometric Analysis of Time Series. Second Edition. Cambridge, MA: MIT Press. 1990.

Hooker, Mark A. 1999. "Oil and the Macroeconomy Revisited." Board of Governors of the Federal Reserve System Finance and Economics Discussion Series 1999-43.

King, Robert G., Charles I. Plosser, James H. Stock, and Mark W. Watson. 1991. "Stochastic Trends and Economic Fluctuations." The American Economic Review. 81:4. p. 819-840.

Kydland, Finn and Edward C. Prescott. 1982. "Time to Build and Aggregate Fluctuations." Econometrica. 50:6. p. 1345-1370.

and ___ 1990. "Business Cycles: Real Facts and a Monetary Myth." Federal Reserve Bank of Minneapolis Quarterly Review. 14:2. p. 4-18.

Liederman, Leonardo. 1983. "The Response of Real Wages to Unanticipated Money Growth." Journal of Monetary Economics. 11:1. p. 73-88.

Long, John B. and Charles I. Plosser. 1983. "Real Business Cycles." Journal of Political Economy. 91:1. p. 39-69.

McCallum, Bennett T. 1986. "On 'Real' and 'Sticky-Price' Theories of the Business Cycle." Journal of Money, Credit, and Banking. 18:4. p. 397-414.

Mankiw, Gregory. 1985. "Small Menu Costs and Large Business Cycles: A Macroeconomic Model of Monopoly." Quarterly Journal of Economics. 100:2. p. 529-539.

Mork, Knut Anton. 1989. "Oil and the Macroeconomy When Prices Go Up and Down: An Extension of Hamilton's Results." Journal of Political Economy. 97:3. p. 740-744. 
Neftci, Salih N. 1978. "A Time-Series Analysis of the Real Wages-Employment Relationship." Journal of Political Economy. 86:2, pt. 1. p. 281-291.

Romer, Christina D. and David H. Romer. 1989. "Does Monetary Policy Matter? A New Test in the Spirit of Friedman and Schwartz." NBER Macroeconomics Annual 1989.

Cambridge: MIT Press. p. 121-170.

Rotemberg, Julio J. and Garth Saloner. 1986. "A Supergame-Theoretic Model of Price Wars during Booms." American Economic Review. 76:2. p. 390-409.

Rotemberg, Julio J. and Lawrence H. Summers. 1990. "Inflexible Prices and Procyclical Productivity." Quarterly Journal of Economics. 105:3. p. 851-874.

Rotemberg, Julio J. and Michael Woodford. 1991. "Markups and the Business Cycle." NBER Macroeconomics Annual 1991. Cambridge: MIT Press. p. 63-129.

and __ 1993. "Imperfect Competition and the Effects of Energy Price Increases on Economic Activity." Unpublished manuscript.

Sargent, Thomas J. 1978. "Estimation of Dynamic Labor Demand Schedules under Rational Expectations." Journal of Political Economy. 86:6. p. 1009-1044.

Shapiro, Matthew D. 1993. "Federal Reserve Policy: Cause and Effect." Forthcoming in Monetary Policy. N. Gregory Mankiw, Ed. Chicago: University of Chicago Press. and Mark W. Watson. 1988. "Sources of Business Cycle Fluctuations" NBER Macroeconomics Annual 1988. Cambridge: MIT Press. p. 111-156.

Solon, Gary, Robert Barsky, and Jonathan A. Parker. 1994. "Measuring the Cyclicality of Real Wages: How Important is Composition Bias?" The Quarterly Journal of Economics. 109:1. p. 1-26.

Sumner, Scott and Stephen Silver. 1989. "Real Wages, Employment, and the Phillips Curve." Journal of Political Economy. 97:3. p. 707-720.

Taylor, John. 1979. "Staggered Wage Setting in a Macro Model." The American Economic Review. 69:2. p. 108-113. 
Table 1

Estimates of Conditional Wage Cyclicality

\section{Correlations of Real Wages and Output in Response to Shocks ${ }^{1}$}

\begin{tabular}{lcc} 
In Response to shock in: & $\begin{array}{c}\text { Eight-Quarter Ahead } \\
\text { Forecast Errors }\end{array}$ & $\begin{array}{c}\text { 16-Quarter Ahead } \\
\text { Forecast Errors }\end{array}$ \\
\hline All Shocks & 0.48 & 0.66 \\
& $(0.15)$ & $(0.16)$ \\
Labor Supply & -0.97 & -0.96 \\
& $(0.69)$ & $(0.70)$ \\
Oil Price & 0.98 & 0.98 \\
& $(0.10)$ & $(0.13)$ \\
Technology & 0.98 & 0.99 \\
Aggregate Demand & $(0.25)$ & $(0.12)$ \\
& -0.49 & -0.32 \\
\end{tabular}

\section{Elasticities of Real Wages with respect to Output in Response to Shocks}

$\begin{array}{lcc}\text { In Response to shock in: } & \text { Eight-Quarter Ahead } & \text { 16-Quarter Ahead } \\ & \text { Forecast Errors } & \text { Forecast Errors }\end{array}$

$\begin{array}{lcc}\text { All Shocks } & 0.26 & 0.42 \\ & (0.09) & (0.13) \\ \text { Labor Supply } & -0.17 & -0.18 \\ & (0.30) & (0.35) \\ \text { Oil Price } & 0.50 & 0.55 \\ & (0.19) & (0.20) \\ \text { Technology } & 0.66 & 0.77 \\ & (0.44) & (0.27) \\ \text { Aggregate Demand } & -0.12 & -0.05 \\ & (0.25) & (0.27)\end{array}$

\footnotetext{
${ }^{1}$ The k-quarter ahead forecast errors are constructed as the moving average coefficients on real wages and output times the realizations of the structural shocks. The forecast errors due to aggregate demand shocks reported are the sum of the two forecast error series due to the individual aggregate demand shocks. Standard errors, in parentheses, are calculated by bootstrapping the residuals 1000 times, regenerating the series at each iteration, and then recalculating the statistics.
} 
Table 2

Decomposition of Forecast Error Variance ${ }^{1}$

Fraction of Forecast Error Variance of Output Explained by Shock to

\begin{tabular}{cccccc} 
Quarter & $\begin{array}{c}\text { Labor } \\
\text { Supply }\end{array}$ & Oil & Technology & $\begin{array}{c}\text { Aggregate } \\
\text { Demand }\end{array}$ & Labor Share \\
\hline 1 & 37.8 & 0.8 & 49.6 & 11.6 & 0.1 \\
& $(21.4)$ & $(3.1)$ & $(21.1)$ & $(16.2)$ & $(6.6)$ \\
4 & 44.2 & 1.3 & 36.7 & 17.1 & 0.7 \\
& $(20.1)$ & $(2.8)$ & $(17.6)$ & $(14.6)$ & $(5.0)$ \\
8 & 39.9 & 9.9 & 37.0 & 12.7 & 0.5 \\
& $(19.2)$ & $(7.0)$ & $(15.4)$ & $(11.4)$ & $(3.6)$ \\
12 & 34.5 & 9.0 & 43.1 & 13.0 & 0.4 \\
& $(18.9)$ & $(6.9)$ & $(15.5)$ & $(10.8)$ & $(2.9)$ \\
20 & 30.1 & 7.9 & 52.8 & 8.9 & 0.3 \\
& $(18.3)$ & $(7.2)$ & $(16.3)$ & $(9.2)$ & $(2.1)$ \\
& 29.5 & 7.2 & 57.3 & 5.7 & 0.3 \\
& $(17.2)$ & $(7.5)$ & $(16.4)$ & $(7.4)$ & $(1.4)$ \\
\hline
\end{tabular}

Fraction of Real Wage Explained by Shock to

\begin{tabular}{cccccc} 
Quarter & $\begin{array}{c}\text { Labor } \\
\text { Supply }\end{array}$ & Oil & Technology & $\begin{array}{c}\text { Aggregate } \\
\text { Demand }\end{array}$ & $\begin{array}{c}\text { Labor } \\
\text { Share }\end{array}$ \\
\hline 1 & 13.1 & 0.0 & 48.3 & 3.3 & 35.3 \\
& $(14.9)$ & $(1.8)$ & $(22.2)$ & $(10.8)$ & $(15.8)$ \\
4 & 9.8 & 3.6 & 65.0 & 2.6 & 18.9 \\
& $(13.8)$ & $(4.5)$ & $(21.1)$ & $(11.5)$ & $(11.1)$ \\
8 & 5.2 & 10.4 & 71.5 & 2.7 & 10.1 \\
& $(10.9)$ & $(8.4)$ & $(19.0)$ & $(11.2)$ & $(7.1)$ \\
12 & 4.4 & 7.7 & 80.3 & 1.4 & 6.2 \\
& $(10.8)$ & $(8.3)$ & $(18.1)$ & $(10.0)$ & $(5.2)$ \\
20 & 2.4 & 6.9 & 87.1 & 0.7 & 2.8 \\
& $(9.3)$ & $(9.5)$ & $(16.5)$ & $(8.3)$ & $(2.9)$ \\
& 1.3 & 6.9 & 89.8 & 0.6 & 1.4 \\
& $(8.0)$ & $(10.6)$ & $(15.3)$ & $(6.6)$ & $(1.8)$ \\
\hline
\end{tabular}

\footnotetext{
${ }^{1}$ Standard errors, in parentheses, are calculated by bootstrapping 1,000 draws from the series of structural shocks, regenerating data series, reestimating the model, and recalculating the variance decompositions Actual oil prices are used in all simulations.
} 
Figure 1

Time Series Plots

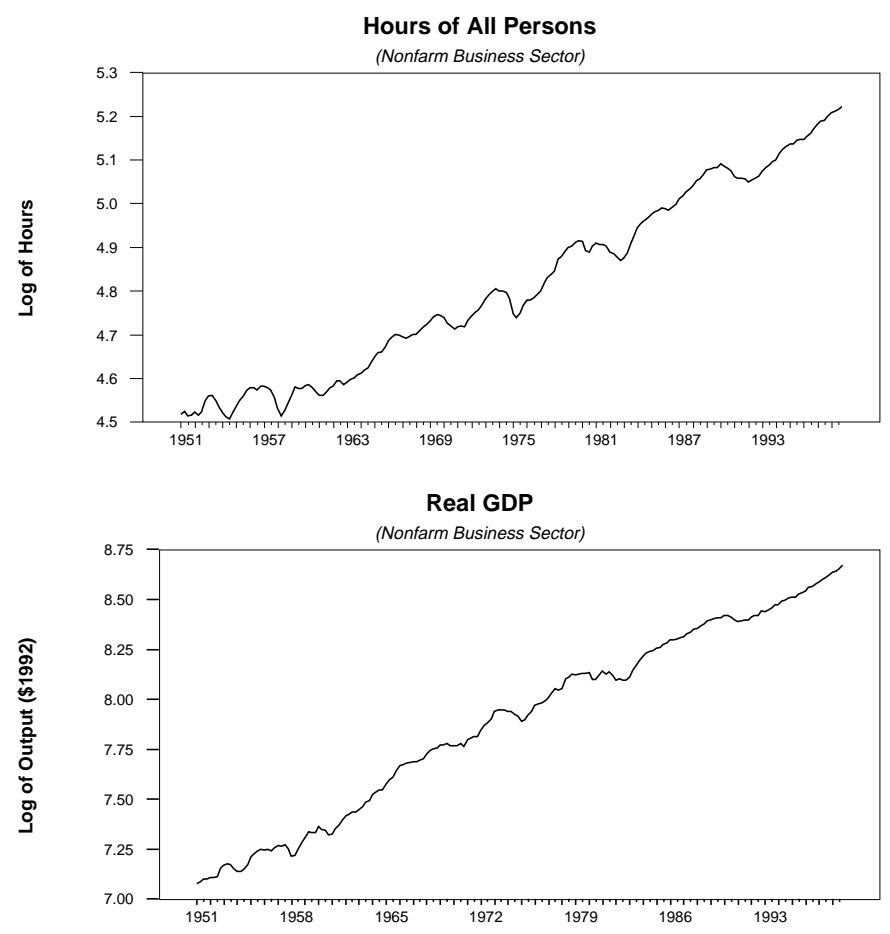

Output per Hour

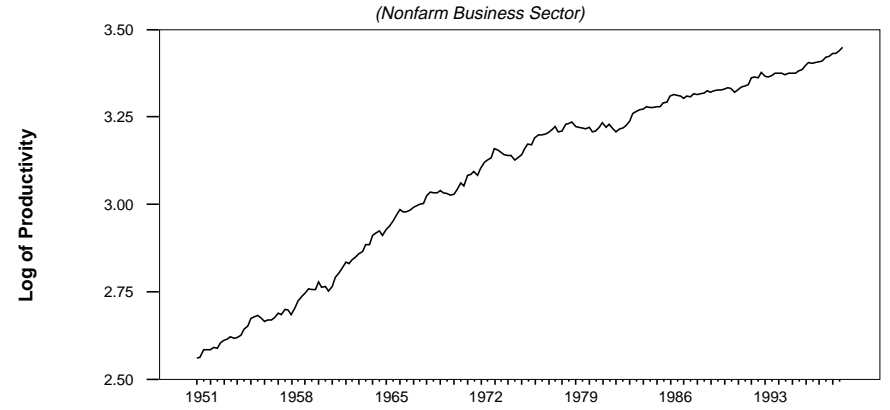

Percentage Change in Implicit Price Deflator

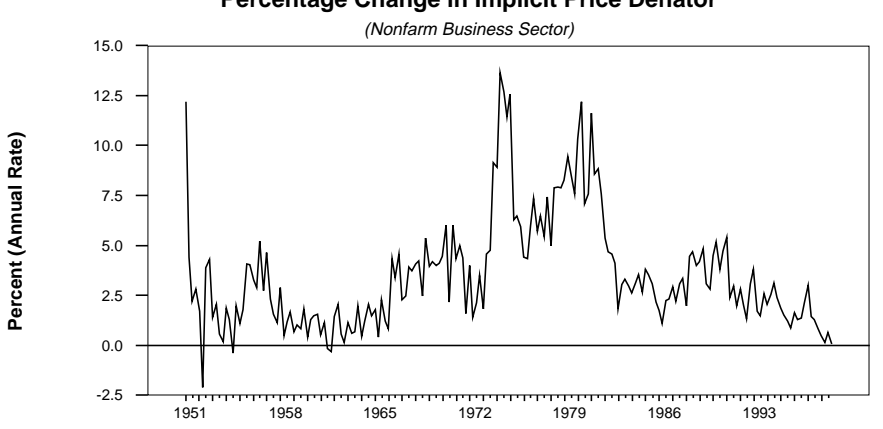

Real (Product) Wages

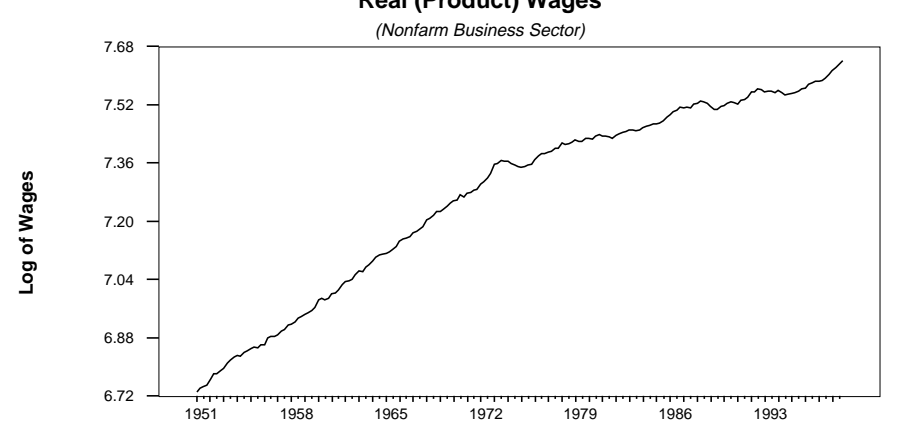

Real Interest Rate

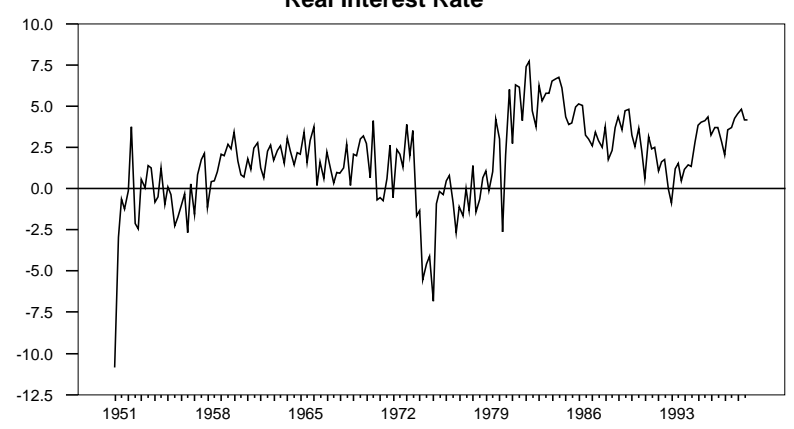

$m$ 


\section{Figure 2}

\section{Real and Nominal Crude Oil Prices}
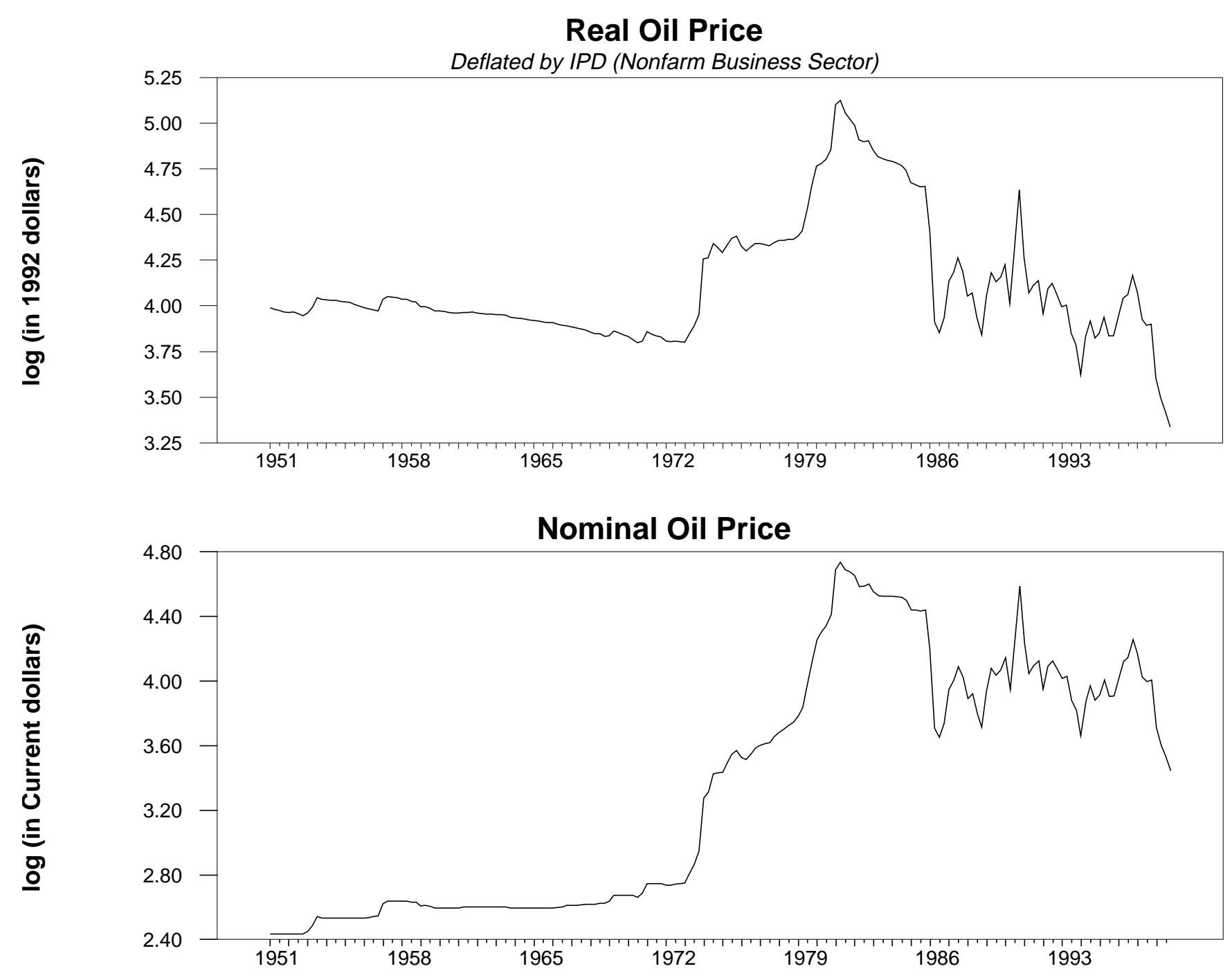
Figure 3: Eight-Quarter Ahead Forecast Errors

Figure 3.a

due to Labor Supply Shocks

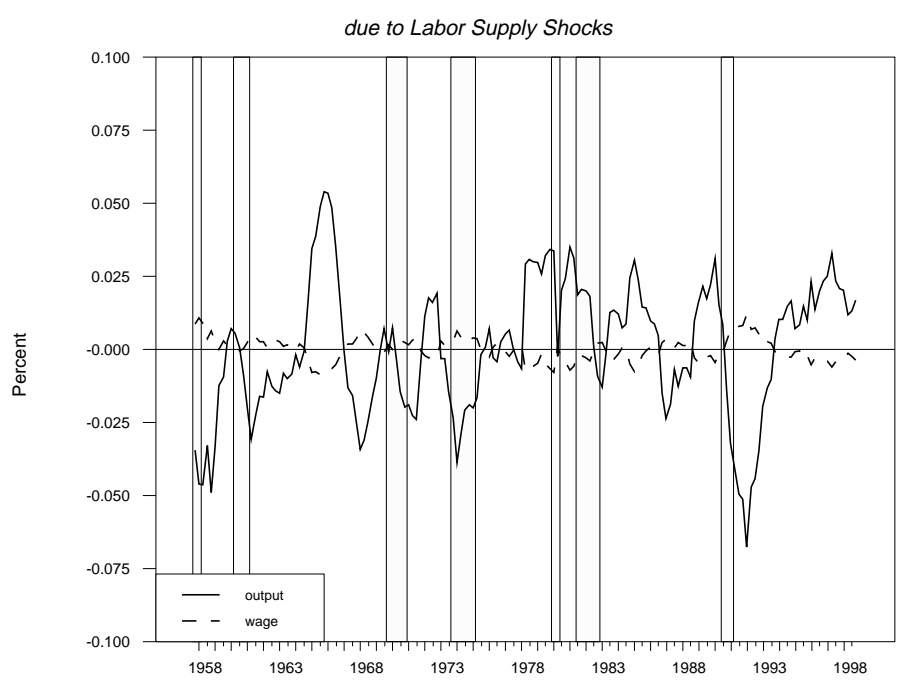

Figure 3.b

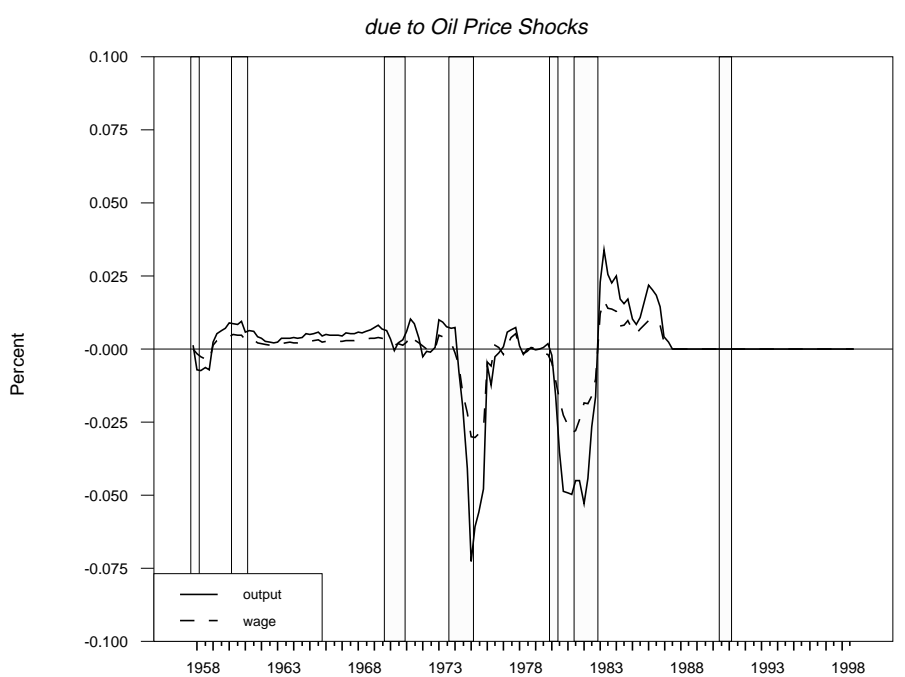

Figure 3.c

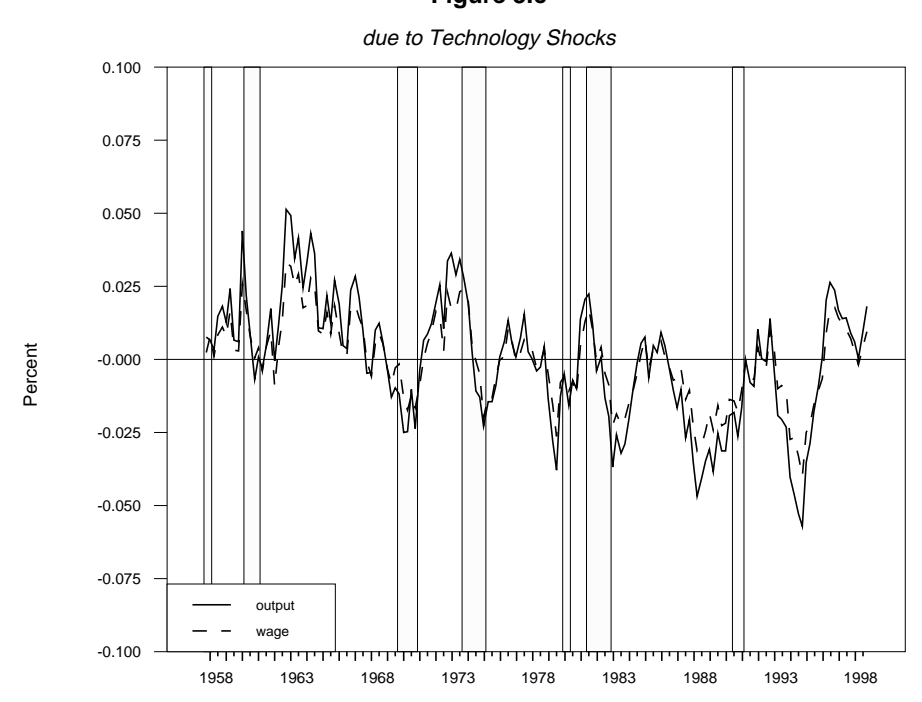

$m$

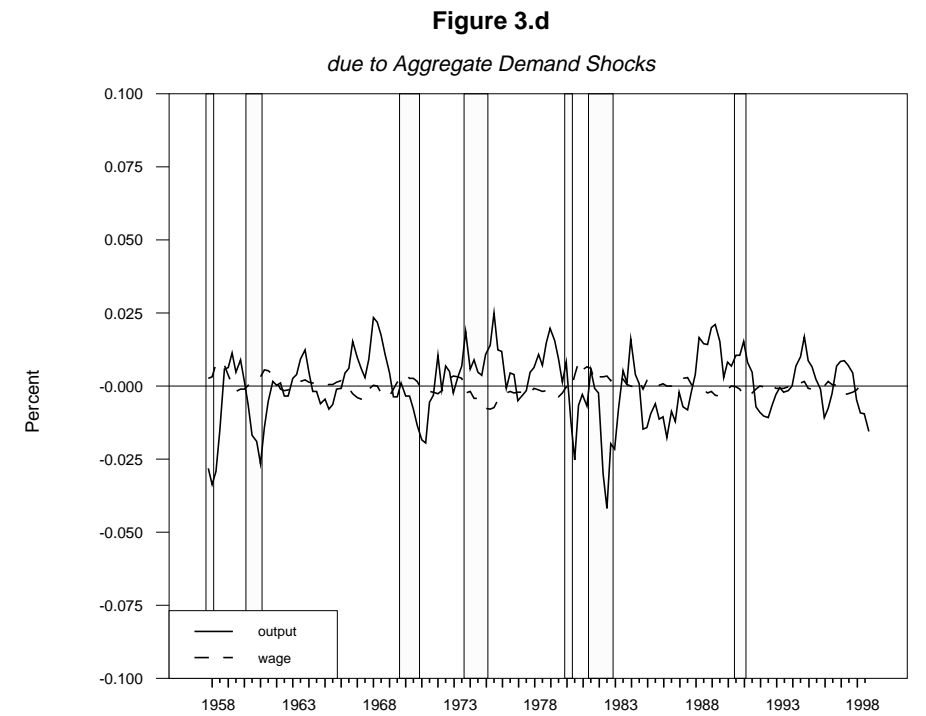




\section{Figure 4}
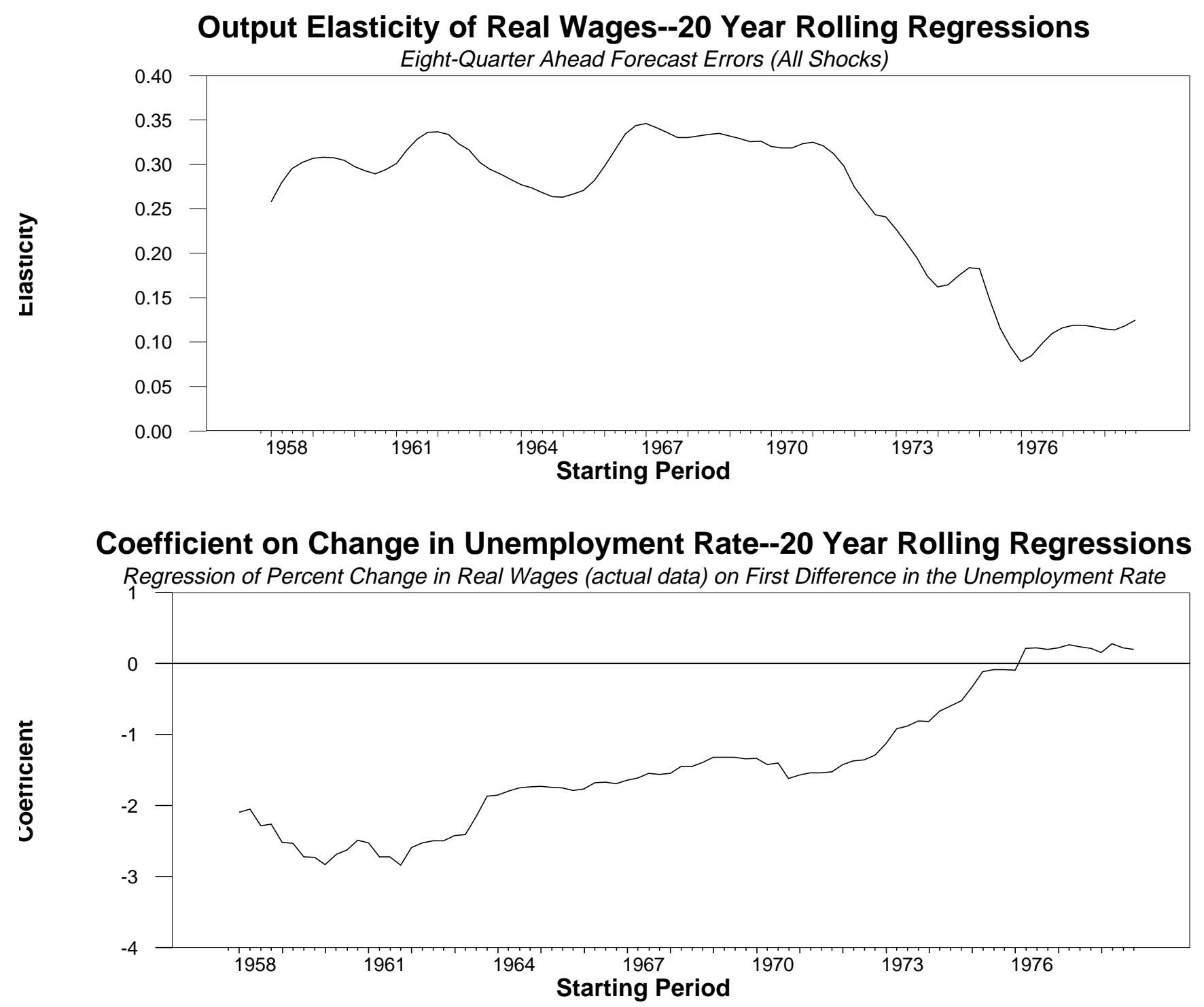